\title{
INVESTIGATION OF THE INFLUENCE OF PLASMA SPRAY SEALING COATINGS ON THE EFFECT OF SEALING THE TV2 - 117A TURBOJET ENGINE COMPRESSOR
}

\author{
Mihailo R. Mrdak \\ Research and Develoopment Center IMTEL, \\ Communications a.d., Belgrade, \\ e-mail: drmrdakmihailo@gmail.com.rs
}

\author{
FIELD: Chemical Technology \\ ARTICLE TYPE: Original Scientific Paper \\ ARTICLE LANGUAGE: English
}

\section{Summary:}

This research shows the effect of the application of soft seals deposited by the atmospheric plasma spraying - APS process on the parts of the TV2-117A turbojet engine compressor. Western plasma spray technology and materials were applied for the first time on the parts of the compressor. The aim was to replace the existing sealant with a new class of materials in order to increase the sealing effect and provide air flow under the highest pressure through the compressor. Soft seals are formed as duplex systems consisting of the bonding underlayer based on NiCrAl and NiAl coatings and top sealing layer coatings based on $\mathrm{Ni}$ $15 \%$ graphite, $\mathrm{Ni}$ - 25\% graphite and AlSi - polyester. This paper presents the parameters for depositing the coatings on the compressor parts as well as the mechanical and microstructural characteristics of the coatings produced with the optimal deposition parameters. The mechanical properties of the coatings were assessed by testing the microhardness of the bonding layers using the $H V_{0.3}$ method and the macrohardness of the sealing layers using the HR15W method. The tensile bond strength of the duplex coatings system was investigated by tensile testing. The microstructures of the coating layers were evaluated on an optical microscope - OM. The analysis of the microstructure of the deposited layers was performed in accordance with the Pratt \& Whitney and TURBOMECA standards. Coating wear was determined from the change in the dimensions of the sealing surfaces before and after testing. The dimensions were measured in the coordinate measuring machine MAUSER ML 28. This paper presents the mean value of wear in milimeters and compares it with the values of the allowed tolerance in the compressor machined parts. The sealing effect of the compressor parts was tested on a TV2-117A engine at a test station and by flight tests on 
an Mi-8 (HT-40) helicopter. The tests have shown that the new system of sealing coatings increases the degree of efficiency of the compressor by $10 \%$ while reducing fuel consumption by $8 \%$.

Key words: Seals, Layers, Engines, Deposits, Compressors, Coatings.

ACKNOWLEDGEMENT: The author is thankful for the financial support from the Ministry of Education and Science of the Republic of Serbia (national projects OI 174004, TR 34016).

\section{Introduction}

Development of new generations of turbo-jet engines and a request for a higher reliability of operation and a wider choice of component resources in exploitation resulted in a wider application of plasma spray coatings. Various quality types of powders have been developed for aircraft components such as low and high pressure compressor components, gas turbine components and landing gear components (Mrdak, 2012b, pp.71-89), (Mrdak, 2013a, pp.69-88), (Vencl, et al., 2011, pp.1281-1288), (Mrdak, et al., 2013, pp.559-567), (Mrdak, 2014a, pp.7-22), (Mrdak, 2014b, pp.7-26). Low and high pressure compressor components of turbojet engines are coated with soft abrasive erosion-resistant coatings which cause low energy conditions of friction. During exploitation, coatings wear instead of causing blade or seam labyrinth wear. These coatings are suitable for eccentric assemblies and they compensate for the changes in machining-induced tolerances. With clearance adjustment to the lowest value, coatings improve engine performances. The precision in machining tolerance is also reflected on a significant reduction of the damage to the blades and on fuel consumption. The most commonly used abrasive coatings are: nickel - graphite, aluminum silicon - polyester, nickel - chromium - iron and aluminum - boron nitride. The quality and resource of abrasive coatings depend on the deposition parameters (Mrdak, 2012b, pp.71-89), (Mrdak, 2013a, pp.69-88). The sealing coating systems are designed in such a way that the rotor non-axiality and the dimension changes due to temperature change are taken into account and that they wear and tear without damage to the blade tops maintaining a constant clearance (Tosnar, 1988, pp.257-262). The blade tops at high speeds must act as an effective cutting tool in order not to damage the seal or the blades. The characteristics which a material should have are good resistance to erosion from foreign particles and a good possibility of wear without damaging the blades as well as the ability to sustain working temperatures without the degradation of mechanical properties (Naser, 1988, pp.75-84). With wearable sealing systems,there is a need for the balance between material wear due to heat, final surface treatment, erosion resistance and resistance to wear. Plasma spray powder deposition parameters enable a con- 
trol of the given key characteristics. The plasma spray deposition process enables the control of coating porosity, density and thicknessin order to obtain sealing layers with the required characteristics (Tosnar, 1988, pp.257262). Soft sealing coatings are formed as duplex systems with plasma spray technology. For the production of the bonding layer, NiAl, NiCrAl and NiCrAlY powders are often used (Mrdak, 2010, pp.5-16), (Mrdak, 2013b, pp.7-22), (Mrdak, 2012a, pp.182-201). The thickness of the bonding layer ranges from 0.005 to $0.15 \mathrm{~mm}$ and must correspond to the substrate material and the top sealing layer. The role of the bonding layer is to provide good adhesion to the substrate and good bonding with the sealing layer. The powders for soft sealing coatings contain metallic components which provide toughness to the coating as well as non-metallic components which are consumed in the process of exploitation, such as graphite, polyester and others. For the production of seals for the temperatures up to $480^{\circ} \mathrm{C}, \mathrm{Ni}$ graphite powder is used due to its high resistance to oxidation, wear and sudden changes in temperature. For lower temperatures, up to $345^{\circ} \mathrm{C}$, coatings based on AISi alloy and polyester mixtures are applied. Thus formed soft sealings provide effective sealing with minimal clearance during engine operation and they reduce the loss of pressurein compressors and turbine sections. World wide research in this field has instigated the use of new materials and plasma spray technology in the process of repair of the TV2117A turbojet engine compressor, produced in Russia. In order to achieve the set goals, the gaps between the components in the compressor must be minimal (Demasi, 1994, pp.1-9). Very good sealing reduces gas loss caused by leakage. Also, seals should provide the thermal insulation of the housing, and reduce the influence of the gas temperature in the casing (Novinski, 1991, pp.451-454), (Yi, 1999, pp.47-53). For that purpose, coatings consisting of a metallic phase and non-metallic phase for self - lubricating with high porosity are used (Oka, 1990, pp.58-67). The most important properties of sealing coatings are high resistance to wear of scraping blades and resistance to gas erosion and foreign particles present in the gas (Novinski, 1990, pp.151-157), (Yi, 1997, pp.99-102).

The aim of the study was to use the plasma spray technology and new materials in order to examine the effect of sealing the TV2 - 117A turbojet engine compressor and to replace the existing sealants during the engine overhaul. New generations of materials applied to seal parts of the engine compressor should provide a higher degree of compressor efficiency with lower fuel consumption. The requirements to be met by such materials are to provide air flow at $\mathrm{T}=100-125^{\circ} \mathrm{C}$ under the highest pressure through the compressor. The expected effects have been confirmed by 42-hour engine tests on the test station and by flight tests of an Mi-8 (HT-40) helicopter. 


\section{Materials and experimental details}

Five different powders of the Sulzer Metco company were used: Metco 443NS, Metco 450NS, Metco 307NS-1, Metco 308NS-1 and Metco 601NS. Bonding coating layers were manufactured from Metco 443NS and Metco 450NS composite powders. Their role is to ensure good bonding of the top sealing layers with the compressor parts and to protect the compressor parts from the external influence of gases.. Particles of Metco 443NS ( NiCr/Al) and Metco 450NS (Ni/Al) composite powders are made by the dry spray technique. The NiCr/Al powder consists of $94 \% \mathrm{NiCr}(75 \% \mathrm{Ni}, 19 \% \mathrm{Cr})$ and $6 \% \mathrm{Al}$. The powder had a granulation range of $-120+45 \mu \mathrm{m}$ (Metco 443NS Nickel-Chromium / Aluminum Composite Powder, 2000, Technical Bulletin 10-130, Sulzer Metco). Composite powder particles of Ni/Al consist of $95.5 \% \mathrm{Ni}$ and $4.5 \% \mathrm{Al}$. The powder had a granulation range of- $88+$ 45 $\mu \mathrm{m}$ (Metco 450NS Nickel / Aluminum Composite Powder, 2000, Technical Bulletin 10-136, Sulzer Metco). For soft sealing coatings intended for operation up to $480^{\circ} \mathrm{C}$, Metco $307 \mathrm{NS}-1$ (Ni/25\% graphite) and Metco $308 \mathrm{NS}-1$ (Ni/15\% graphite)composite powders were used (Metco 307NS 1, Metco 308NS - 1 Nickel Graphite Powder, 2000, Technical Bulletin 10115, Sulzer Metco). Powders are manufactured by cladding graphite particles with Ni particles by the dry spray method. The powders had a range granulation of $90+30 \mu \mathrm{m}$ (Metco 307NS - 1, Metco 308NS - 1 Nickel Graphite Powder, 2000, Technical Bulletin 10-115, Sulzer Metco). To produce a soft sealing designed for operations up to $345^{\circ} \mathrm{C}$, a mechanical mixture of powders AISi12 and polyester was used. The powder consists of $60 \%$ of the AlSi12 alloy and $40 \%$ of polyester. The powder had a granulation particles of a range of - $106+10 \mu \mathrm{m}$ (Metco 601NS Aluminum - Polyester Powder, 2000, Technical Bulletin 10-141, Sulzer Metco). The substrate material of the samples on which the layers of the sealing coating system were deposited was made of stainless steel $\mathrm{X} 15 \mathrm{Cr} 13$ (EN 1.4024) in the thermally unprocessed state. The testing of the mechanical properties of the coating layers was done in accordance with the Pratt \& Whitney standard (Turbojet Engine - Standard Practices Manual (PN 582005), 2002, Pratt \& Whitney, East Hartford, USA) and TURBOMECA standard (Turbojet engine-standard practices manual, TURBOMECA). For hardness testing and the evaluation of the microstructure of sealing coatings in the deposited state, C.4171 (X15Cr13 EN10027) steel samples were made, with the dimensions $70 \times 20 \times 1.5 \mathrm{~mm}$. The microhardness of the NiAl and NiCrAl coating bond was tested using the $\mathrm{HV}_{0.3}$ method and the macrohardness of $\mathrm{Ni}-15 \%$ graphite, $\mathrm{Ni}-25 \%$ graphite and AlSi12 polyester sealing coatings was tested using the HR15y method with a Rockwell steel ball of $12.7 \mathrm{~mm}$ in diameter and a load of $15 \mathrm{~kg}$. The macrohardness of the coatings was measured along the layers. Out of five performed readings of the hardness values of the layers in 
the middle and at the ends of the samples, two extreme values were rejected. The three remaining values are shown in their minimum and maximum values. The samples for testing bond strength were made of the same steel with the dimensions of $\varnothing 25 \times 50 \mathrm{~mm}$. Tensile tests were carried out at room temperature on the hydraulic equipment at a rate of $10 \mathrm{~mm} / \mathrm{min}$. For each compression part,a relevant groups of samples,three specimens for each part, were made. The samples were rotated together with the compressor parts at a certain rotational speed in order to obtain the same conditions of depositing sealing coatings. The results obtained were averaged and the bond strength mean values are shown in the paper.

The microstructure of the deposited layers was examined on an optical microscope - OM. The analysis of the share of micro pores in the coating was performed by treating 5 photos at 200X magnification. The paper presents the mean values of the share of micro pores in the coating. Table 1 contains the names of the TV2-117A turbojet engine compressor parts, types of material the parts were made of as well as the working conditions for the parts with deposited new systems of sealing coatings.

The compressor consists of focusing devices of IV - IX degrees, compressor front body, compressor working rings of $V$ degree to $X$ degree and the air labyrinth ring made of titanium alloy intended for military aviation industry. The titanium alloy has the Russian designation OST 1 90173-75 (VT-5) and the aluminum content of 4.3-6.2\% Al.

Table 1 - Parts of the TV2-117A turbo-jet engine compressor

Tabela 1 - Delovi kompresora turbo-mlaznog motora TV2-117A

\begin{tabular}{|l|l|l|l|}
\hline No. & Name of parts & Material & Working conditions \\
\hline 1. & $\begin{array}{l}\text { Compressor focusing devices } \\
\text { of IV degree to IX degree }\end{array}$ & VT-5 & $\begin{array}{l}\text { Air } \\
\mathrm{t}=100-125^{\circ} \mathrm{C}, \\
\mathrm{P}=4-7 \mathrm{bar}\end{array}$ \\
\hline 2. & Compressor front body & VT-5 & $\begin{array}{l}\text { Air } \\
\mathrm{t}=100^{\circ} \mathrm{C}, \\
\mathrm{P}=4 \mathrm{bar}\end{array}$ \\
\hline 3. & $\begin{array}{l}\text { Compressor working rings } \\
\text { of V degree to X degree }\end{array}$ & VT-5 & $\begin{array}{l}\text { Air } \\
\mathrm{t}=100-125^{\circ} \mathrm{C}, \\
\mathrm{P}=4-7 \mathrm{bar}\end{array}$ \\
\hline 4. & Air labyrinth ring & VT-5 & $\begin{array}{l}\text { Air } \\
\mathrm{t}=100-125^{\circ} \mathrm{C} \mathrm{P}=4 \mathrm{bar}\end{array}$ \\
\hline
\end{tabular}

The powder manufacturer, Sulcer Metko, prescribed that the powder should be deposited by its plasma spray systems labeled Metco 9M, 7M and $3 \mathrm{M}$ applying the prescribed deposition parameters. Therefore, the application of other plasma spray depositing systems requires that the depositing parameters must be tested and optimized. In previously published works (Mrdak, 2012b, pp.71-89), (Mrdak, 2013a, pp.69-88), the parameters for SG100 and MINI - GUN II plasma guns of the Plasmadyne company were opti- 
mised using fixed samples on special tools. To obtain identical microstructures and mechanical properties of the sealing coating system on the accompanying samples and on the cylindrical parts of the compressor, the deposition of powders was performed in specially made tools for the deposition on both the compressor parts and specimens. The deposition of powders was performed under the same conditions on the samples and the compressor parts with a particular rotational speed and the plasma gun rate.

In this experiment, the atmospheric plasma system of the Plazmadayn company and the plasma gun MINI - GUN II were used. Numerous samples were made and the paper presents the optimal parameters used for depositing coatings on the compressor parts and tested on the TV2-117A turbojet engine at the test station and on an Mi-8 (HT-40) helicopter intended for flight tests. The coatings were deposited on the roughened and preheated samples and compressor parts at a temperature of $90-120^{\circ} \mathrm{C}$. Because of the geometry of the parts - the focusing devices of IV - IX degrees, the front of the compressor body, the compressor work rings of $\mathrm{V}$ $X$ degrees and the air ring labyrinth - the powder depositing was done with a specially constructed plasma gun MINI - GUN II, with the dimensions $\varnothing 25 \mathrm{X}$ $600 \mathrm{~mm}$. The plasma gun consisted of: A 2084 - F65 anode, K1083 - 129 cathode and Gl2084 B - 103 gas injector. The deposition of all the coatings was performed with the power supply of $40 \mathrm{KW}$. The bond layers of NiCrAl and $\mathrm{NiAl}$ coatings were deposited with an Ar-He mixture of plasma gases, while the sealing layers of the coatings with Ar were deposited withhout the secondary plasma gas of He.

Three types of systems of sealing coatingswere made: NiCrAl/Ni - 15\% graphite, NiCrAl/Ni - 25\% graphite and NiAl/AlSi12 - polyester. In all parts, the thickness of the NiCrAl bond layers with a single pass of the plasma gun was $25 \mu \mathrm{m}$. The thickness of the sealing $\mathrm{Ni}-15 \%$ graphite and $\mathrm{Ni}-25 \%$ graphite layers with a single pass of the plasma gun was $60 \mu \mathrm{m}$. The thickness of the NiAl layer on the air labyrinth ring with a single pass of the plasma gun was $20 \mu \mathrm{m}$. The thickness of the sealing AISi12 - polyester layer on the air ring with one pass of the plasma gun was $100 \mu \mathrm{m}$.

Table 2 shows the plasma spray parameters of the powders deposited with a MINI - GUN II plasma gun on the focusing devices of IV degree to IX degree. The thickness of the bond layers deposited with the NiCrAl powder was from 0.1 to $0.15 \mathrm{~mm}$, and the thickness of the sealing coatings made of the powder of $\mathrm{Ni}-25 \%$ of graphite was 0.65 to $0.7 \mathrm{~mm}$. The sealing coating thicknesses were increased by $0.3 \mathrm{~mm}$ for machining purposes.

At the front of the compressor body, the thickness of the bond layers with the deposited NiAl powder was from 0.1 to $0.15 \mathrm{~mm}$, and the thickness of the top layer of the sealing coating made of the powder of $\mathrm{Ni}-15 \%$ of graphite was from 0.65 to $0.7 \mathrm{~mm}$. The sealing coating thicknesses were increased by $0.3 \mathrm{~mm}$ for machining purposes. 
Table 2 - Plasma spray parameters

Tabela 2 - Plazma sprej parametri

\begin{tabular}{|l|c|c|c|c|c|}
\hline Deposition parameters & NiCrAl & $\begin{array}{c}\mathrm{Ni}-15 \% \\
\text { graphite }\end{array}$ & $\begin{array}{c}\mathrm{Ni}-25 \% \\
\text { graphite }\end{array}$ & $\mathrm{NiAl}$ & $\begin{array}{c}\text { AlSi12- } \\
\text { polyester }\end{array}$ \\
\hline Plasma current, (A) & 800 & 700 & 700 & 800 & 700 \\
\hline Plasma Voltage, (V) & 39 & 38 & 38 & 39 & 38 \\
\hline $\begin{array}{l}\text { Primary plasma gas flow } \\
\text { rate, Ar (I/min ) }\end{array}$ & 75 & 75 & 75 & 75 & 75 \\
\hline $\begin{array}{l}\text { Secondary plasma gas } \\
\text { flow rate, He (I/min) }\end{array}$ & 50 & -- & -- & 50 & -- \\
\hline $\begin{array}{l}\text { Carrier gas flow rate, } \\
\text { Ar (I/min ) }\end{array}$ & 7 & 9 & 9 & 7 & 6 \\
\hline $\begin{array}{l}\text { Rotation of the powder } \\
\text { disk, ( o/min ) }\end{array}$ & 2.5 & 3.2 & 3.2 & 2.5 & 4.5 \\
\hline $\begin{array}{l}\text { Stand-off distance of the } \\
\text { plasma gun, ( mm ) }\end{array}$ & 60 & 65 & 65 & 60 & 80 \\
\hline $\begin{array}{l}\text { Circumferential speed } \\
\text { of the part } \\
\text { ( mm/s ) }\end{array}$ & 500 & 250 & 250 & 500 & 250 \\
\hline $\begin{array}{l}\text { Plasma gun rate, } \\
\text { ( mm/s ) }\end{array}$ & 3 & 3 & 3 & 3 & 3 \\
\hline
\end{tabular}

On the compressor working rings of the $\mathrm{V}-\mathrm{X}$ degrees, the bond layers of the NiCrAl coatings were deposited with a thickness of 0.15 to $0.2 \mathrm{~mm}$. The thicknesses of the top sealing coatings deposited with powder $\mathrm{Ni}-25 \%$ of graphite were thicknesses of 0.8 to $0.85 \mathrm{~mm}$. Also, for machining purposes, the coating thicknesses of the sealing coatings were increased by $0.3 \mathrm{~mm}$.

On the air labyrinth ring, the coating bond layer is made of $\mathrm{NiAl}$ powder with a thickness of 0.1 to $0.15 \mathrm{~mm}$, and the top sealing layer of the coating is made of AlSi12-polyester powder with a thickness of 0.6 $0.65 \mathrm{~mm}$. The thickness of the sealing layer includes the additional 0.3 $\mathrm{mm}$ for machining purposes.

The machining of the $\mathrm{Ni}-15 \%$ graphite and $\mathrm{Ni}-25 \%$ graphite sealing coatings deposited on the compressor parts was performed using the method of coarse finishing of scuffing and fine finishing of scuffing with cutting tools - a knife with a WC plate. During the machining, no cooling of the machining surface was applied.. Table 3 shows the parameters of the machining of $\mathrm{Ni}-15 \%$ graphite and $\mathrm{Ni}-25 \%$ graphite coatings deposited on the compressor focusing device of IV - IX degrees, the compressor front body and the compressor working rings of $\mathrm{V}-\mathrm{X}$ degrees. 
Table 3 - Parameters of machining Ni - 15\% graphite and 25\% Ni graphite coatings

Tabela 3 - Parametri mašinske obrade $\mathrm{Ni}-15 \%$ grafit i Ni $-25 \%$ grafit prevlaka

\begin{tabular}{|l|c|c|c|c|}
\hline \multicolumn{1}{|c|}{ Methods } & $\begin{array}{c}\text { Depth of cut } \\
\text { per pass } \\
\mathrm{mm}\end{array}$ & $\begin{array}{c}\text { Number of } \\
\text { revolutions } \\
\text { o/min }\end{array}$ & $\begin{array}{c}\text { Gait } \\
\mathrm{mm} / \mathrm{o}\end{array}$ & $\begin{array}{c}\text { roughness } \\
\mu \mathrm{m}\end{array}$ \\
\hline $\begin{array}{l}\text { Coarse finishing } \\
\text { of scuffing }\end{array}$ & $0.2-0.5$ & $30-60$ & 0.1 & $10-15$ \\
\hline $\begin{array}{l}\text { Fine finishing } \\
\text { of scuffing }\end{array}$ & $0.1-0.2$ & $30-60$ & 0.1 & $10-15$ \\
\hline
\end{tabular}

Table 4 shows the parameters of machining the AISi12 - polyester coating deposited on the air labyrinth ring. The machining of the coating was done by combining coarse and fine grinding finishing. During machining, the treated surface was cooled.

Table 4 - Parameters of machining the AISi12 - polyester coating

Tabela 4 - Parametri mašinske obrade AISi12 - poliester prevlake

\begin{tabular}{|l|c|c|c|c|c|}
\hline \multicolumn{1}{|c|}{ Methods } & Cutting tools & Sign & $\begin{array}{c}\text { Cutting } \\
\text { speed } \\
\mathrm{m} / \mathrm{min}\end{array}$ & $\begin{array}{c}\text { Number of } \\
\text { revolutions } \\
\text { o/min }\end{array}$ & $\begin{array}{c}\text { Step } \\
\mathrm{mm} / \mathrm{o}\end{array}$ \\
\hline $\begin{array}{l}\text { Coarse } \\
\text { finishing } \\
\text { of scuffing }\end{array}$ & $\begin{array}{c}\text { Knife with plate } \\
\text { WC }\end{array}$ & $\begin{array}{c}\text { WC } \\
\mathrm{r}=0.5\end{array}$ & 150 & $20-30$ & 0.2 \\
\hline $\begin{array}{l}\text { Fine finishing } \\
\text { of scuffing }\end{array}$ & Diamond knife & $\begin{array}{c}\text { WC } \\
\mathrm{r}=0.5\end{array}$ & 150 & 30 & 0.04 \\
\hline
\end{tabular}

The investigation of the coating sealing effect on the parts of the compressor was done at a test station with the operating time of the TV2117A turbojet engine of 42 hours and on an Mi-8 (HT-40) helicopter intended for testing.

The coating wear was determined based on the change in size of the sealing surfaces before and after the testing. The measurement of the dimesions was done on a MAUSER ML 28 coordinate measuring machine at eight measuring points around the perimeter of the cylindrical parts. This paper presents the mean wear value of sealing coatings in $\mathrm{mm}$, compared with the values of the allowed tolerance of machineprocessed parts of the compressor. 


\section{Results and discussion}

Figure 1 shows a part of the focusing device of IV to IX degrees of the TV2 - 117A turbojet engine compressor on which the system of $\mathrm{NiCrAl} / \mathrm{Ni}-25 \%$ graphite sealing coatings was deposited. The figure shows the microstructures of the bond coating (a) and the top sealing coating (b). The layers of the NiCrAl bond coating are evenly deposited on the focusing device with good mechanical properties and structural characteristics. The red arrows mark the surfaces where the system of sealing coatings was deposited.

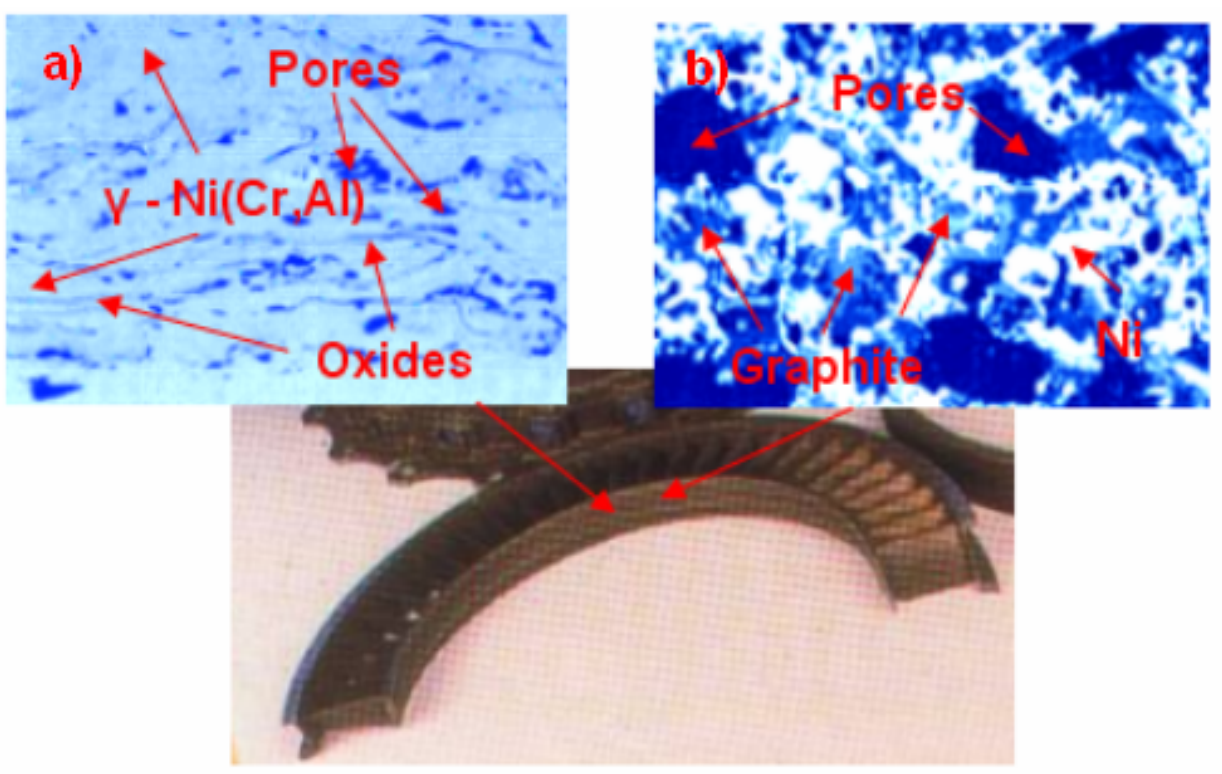

Figure 1 - Part of the focusing device of IV - IX degrees of the compressor and the microstructures of the system of the $\mathrm{NiCrAl} / \mathrm{Ni}-25 \%$ graphite sealing coatings

Slika 1 - Deo usmeravajućeg aparata od IV - IX stepena kompresora i mikrostrukture sistema zaptivne prevlake NiCrAl/ Ni-25\%grafit

The NiCrAl bond coating had the microhardness values of 308-325 $\mathrm{HV}_{0.3}$. The values are above min. $170 \mathrm{HV}_{0.3}$ prescribed by the standard (Turbojet engine-standard practices Manuel, Turbomeca). The even microhardness values indicate an even distribution of oxides and pores in the deposited layers. The tensile bond strength of the system of $\mathrm{NiCrAl} / \mathrm{Ni}-25 \%$ graphite coatings had a value of $43 \mathrm{MPa}$ and is above the minimum value of $32 \mathrm{MPa}$ prescribed by the standard (Turbojet engine-standard practices Manuel, Turbomeca). The character of the de- 
struction of the coatings was the adhesion on the coating / substrate interface, which indicates the good cohesive strength of the coating lamellae. The analysis of the micrographs revealed that in the NiCrAl coating bond layers the proportion of micro pores was under $2 \%$. The coating consists of the lamellae of the solid solution of chromium and aluminum in light blue $\mathrm{y}-\mathrm{Ni}(\mathrm{Cr}, \mathrm{Al})$ nickel and inter-lamellar oxide phases of $\mathrm{NiO}$, $\mathrm{NiCr}_{2} \mathrm{O}_{3}, \mathrm{Cr}_{2} \mathrm{O}_{3}, \mathrm{CrO}_{3}$ evenly distributed on the boundaries of the lamellae of the solid solution, dark blue in color and marked with red arrows (Brossard, et al., 2009, pp.1-9), (Mrdak, 2012, pp.5-16), (Mrdak, 2012a, pp.182-201). The oxides formed during the deposition of the powder which reacts with the oxygen from the air and with the oxygen incorporated into the plasma jet from the surrounding atmosphere. In the coating layers, there are also micro pores, dark blue, marked with red arrows. In the coating layers, unmelted particles and precipitates are not present. The $\mathrm{Ni}-25 \%$ graphite sealing coating had the macrohardness values in the range of 78-83 HR15y. The hardness values were quite even, which indicates that the layers of the $\mathrm{Ni}-25 \%$ graphite coating were continuously and uniformly deposited on the bond layers. This was confirmed by the metallographic examination of the coatings. At the cross section of $\mathrm{Ni}-25 \%$ graphite coating there are no unmelted particles, micro cracks networks or macro cracks, which is of essential importance for the good functionality of coatings in exploitation. The structure of $\mathrm{Ni}$ $25 \%$ graphite coating is lamellar. Nickel, white, is uniformly deposited throughout the cross section, which gives good strength to the coating as well as toughness, and resistance to oxidation, corrosion and erosion. The graphite in light blue marked by red arrows is, as a solid lubricant and a means to control the porosity, uniformly distributed in the coating. It is surrounded and closed by a metal base of $\mathrm{Ni}$, which is very important because it increases the resistance of graphite sealing coatings to thermal shocks. Between the $\mathrm{Ni}$ and graphite lamellae, there are micro pores in dark blue. The analysis of the micrographs have shown that the proportion of micro pores was $16 \%$ in the layers of $\mathrm{Ni}-25 \%$ graphite sealing coating, which is in accordance with the standards and the regulations of the powder manufacturer.

Figure 2 shows the front body of the TV2 - 117 A turbojet engine compressor, consisting of two halves. The red arrows mark the places on the compressor body where the systems of $\mathrm{NiAl} / \mathrm{Ni}-15 \%$ graphite sealing coatings are deposited. Figure 2(a) shows the microstructure of the NiAl bond coating and Figure 2 (b) shows the microstructure of the top $15 \% \mathrm{Ni}$-graphite sealing coating. The NiAl bond coating had the microhardness values of $165-181 \mathrm{HV}_{0.3}$, and the layers of $\mathrm{Ni}-15 \%$ graphite sealing coatings from 86 to $89 \mathrm{HR} 15 \mathrm{y}$. The sealing system of the $\mathrm{NiAl} / \mathrm{Ni}-$ $15 \%$ graphite coating had a value of the bond tensile strength of $44 \mathrm{MPa}$. 


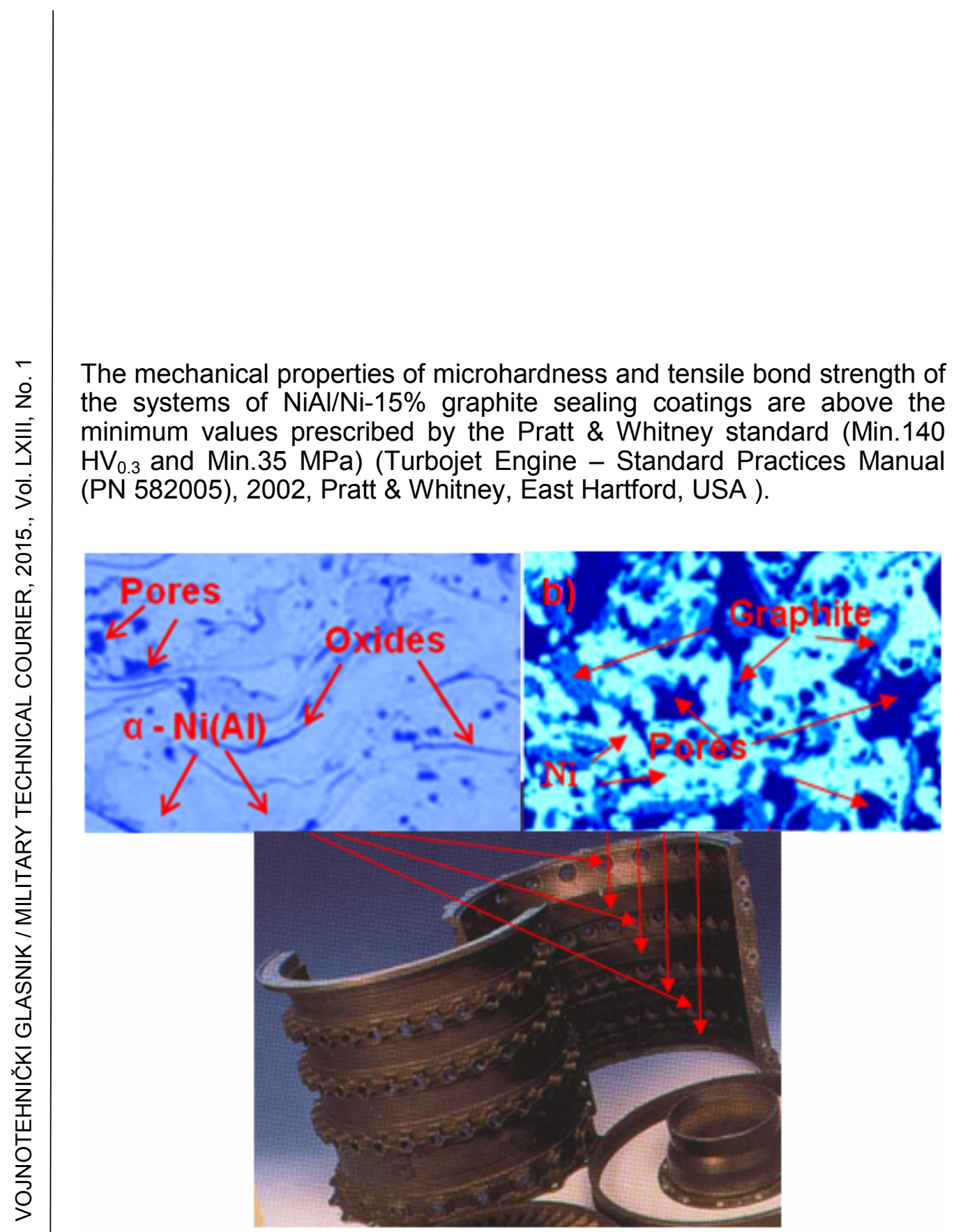

Figure 2 - The compressor front body in the TV2 - $117 \mathrm{~A}$ turbojet engine and the microstructures of the system of the NiAl / Ni-15\% graphite sealing coating Slika 2 - Prednje telo kompresora turbomlaznog motora TV2 - 117 A i mikrostrukture sistema zaptivne prevlake $\mathrm{NiAl} / \mathrm{Ni}-15 \%$ grafit

The character of the coatings system destruction was the adhesion at the coating / substrate interface. The analysis of the micrographs of the $\mathrm{NiAl}$ bond coating showed that the proportion of pores was below $2 \%$. In the layers of the $\mathrm{Ni}-15 \%$ graphite sealing coating the proportion of micro pores was $13 \%$, which is a lower proportion compared to the $\mathrm{Ni}-25 \%$ graphite sealing coating. The microstructure of the NiAl bond coating is lamellar. The coating consists of a lamella of the solid solution of aluminum in nickel $\alpha-\mathrm{Ni}(\mathrm{Al})$, light blue, and $\mathrm{NiO}$ and $\mathrm{y}-\mathrm{Al}_{2} \mathrm{O}_{3}$ inter-lamellar oxides 
evenly distributed over the lamellae solid solution boundaries, dark blue and marked with red arrows (Knotek, et al.,1980, pp.282-286), (Mrdak, 2013b, pp.7-22), (Svantesson, Wigren, 1992, pp.65-69).

Figure 3 shows the air labyrinth ring (1) and the working ring of the compressor of the $\mathrm{V}-\mathrm{X}$ degrees (2) of the TV2 - 117A turbojet engine.

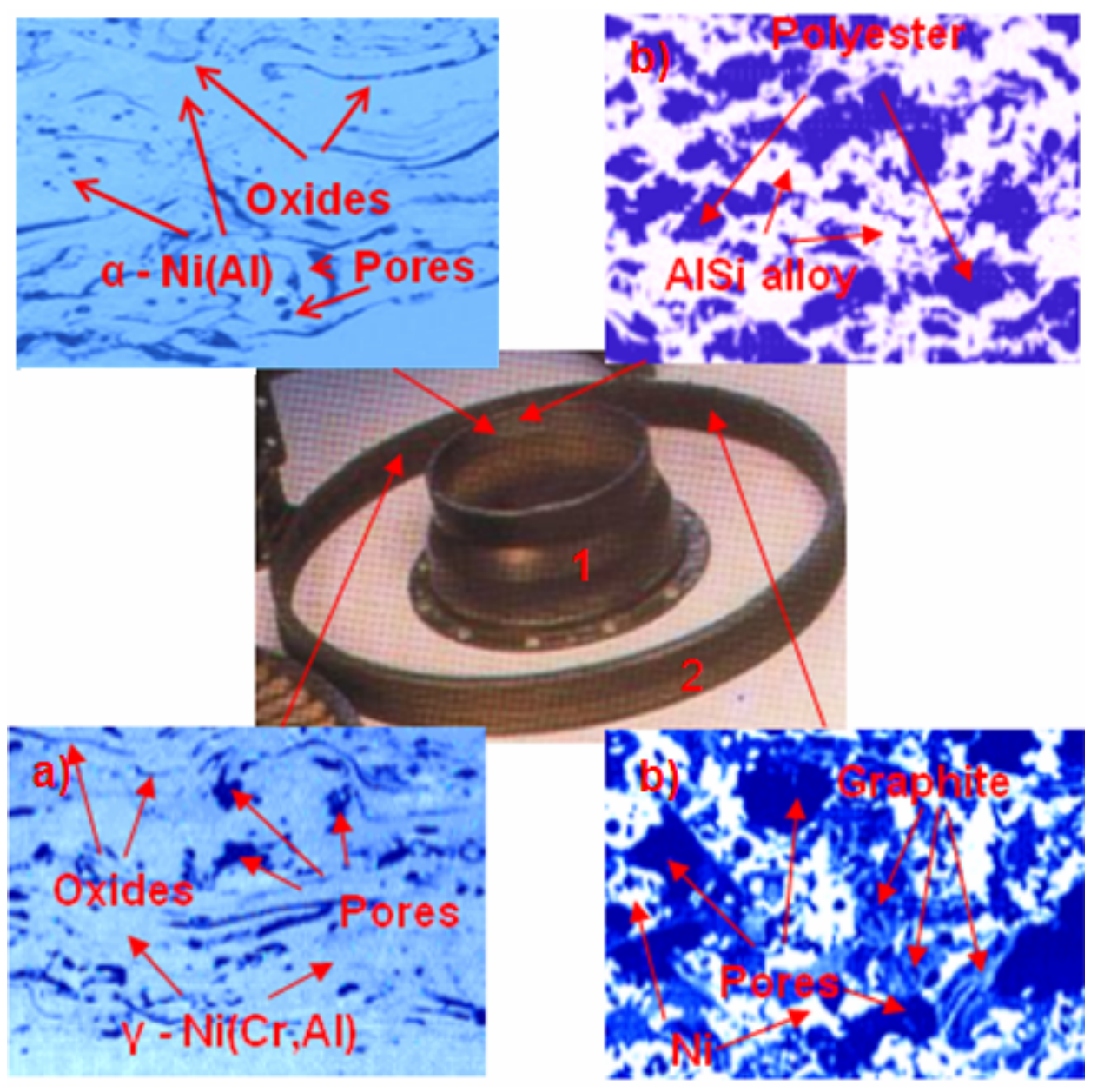

Figure 3 - Air labyrinth ring (1) with the microstructure of the NiAl / AISi12 polyester coating system and the working ring of the compressor of the $\mathrm{V}-\mathrm{X}$ degrees (2) with the microstructure of the $\mathrm{NiCrAl} / \mathrm{Ni}-25 \%$ graphite coating system

Slika 3 - Prsten vazdušnog labirinta (1) sa mikrostrukturama sistema prevlaka $\mathrm{NiAl} /$ AISi12 poliester i radni prsten kompresora od V - X stepena (2) sa mikrostrukturama sistema prevlaka NiCrAl / Ni-25\%grafit 
The air labyrinth ring is marked with number 1 and the red arrows mark the surface on which the NiAl/AISi12-poliester sealing coating system was deposited. Figure (a) shows the microstructure of the NiAl bond coating, and (b) the microstructure of the top AISi12- poliester sealing coating. The NiAl bond coating was deposited with the values of microhardness of $178-203 \mathrm{HV}_{0.3}$, and the AISi12-polyester sealing coating with the values of 72-75 HR15y. The hardness values of the coatings are very even, which indicates a smooth and continuous deposition of coating layers on the substrate. The tensile bond strength of the AISi12 - polyester sealing coating in the system with the NiAl bond coating was $30 \mathrm{MPa}$. The mechanical properties were consistent with the Pratt \& Whitney Standard (Turbojet Engine - Standard Practices Manual (PN 582005), 2002, Pratt \& Whitney, East Hartford, USA) and with the characteristics prescribed by the powder manufacturers. In the microstructure of the NiAl bond coating whose base consists of a solid solution of aluminum in nickel $\alpha-\mathrm{Ni}(\mathrm{Al})$ in light blue, there are $\mathrm{NiO}$ and $\mathrm{y}^{-}$ $\mathrm{Al}_{2} \mathrm{O}_{3}$ oxides and micro pores as in the previous micrographs shown in Figure 2(a). The analysis of the micrographs of the NiAl bond coating showed that the proportion of micro pores was about $2 \%$. The microstructure of the AISi12 - polyester sealing coating consists of an AlSi12 alloy (white) which gives strength to the coating as well as resistance to erosion and provides a good bonding of AISi12 particles with NiAl bond coating particles. The cross section of the AISi12 polyester coating does not show unmelted particles or the network of micro and macro cracks, which is very important for the behavior of the coatings during the compressor operation. The second phase of polyester which serves as a solid lubricant for wear control and maintaining a constant gap during the compressor operation is surrounded, and thus closed, by the metal base of the AISi12 alloy. Thus formed structure of the sealing coating helps to reduce the transmission of the coating on the blades and to reduce the coating breaking or erosion. The analysis of photomicrographs of the AISi12 sealing coating showed that the proportion of micro pores was $5 \%$. In Figure 3 (b) it can be seen that the layers of AISi12 and the polyester have a continuous mesh structure. The network of polyester is given in blue.

Number 2 in Figure 3 marks the working ring and the red arrows mark the surface on which the $\mathrm{NiCrAl} / \mathrm{Ni}-25 \%$ graphite sealing coating system was deposited. The photomicrograph (a) shows the microstructure of the NiCrAl bond coating and (b) shows the microstructure of the top $\mathrm{Ni}-25 \%$ graphite sealing coating. The NiCrAl bond coating had the microhardness values of $305-331 \mathrm{HV}_{0.3}$. The $\mathrm{Ni}-25 \%$ graphite sealing 
coating had the macrohardness values within the range of 79-84 HR15y. The NiCrAl / Ni - 25\% graphite sealing coating system had the bond strength value of $43 \mathrm{MPa}$. The microhardness values and tensile bond strength values are above the minimum values prescribed by the TURBOMECA standard (min. $170 \mathrm{HV}_{0.3}$ and $35 \mathrm{MPa}$ ) (Turbojet engine - standard practices manuel, TURBOMECA). The structure of the NiCrAl coating layer is a lamellar microstructure described above, which consists of a solid solution of $\mathrm{y}-\mathrm{Ni}(\mathrm{Cr}, \mathrm{Al})$ in light blue and oxide phases in dark blue. Between the lamellae of the substrate and the lamellae of oxide phases, there are micro pores in dark blue marked with red arrows (Brossard, et al., 2009, pp.1-9), (Mrdak, 2012, pp.5-16), (Mrdak, 2012a, pp.182-201). In the structure of the $\mathrm{Ni}-25 \%$ graphite coating,a metal network of $\mathrm{Ni}$ in white can be seen. Particles of graphite in light blue are evenly distributed in the Ni network. Micro pores are dark blue, clearly distinct and marked with red arrows. The analysis of the photomicrographs has shown that, in the NiCrAl coating layers, the share of micro pores was below $2 \%$, and in the $\mathrm{Ni}-25 \%$ graphite coating layers it was $17 \%$, which is in accordance with the standards and recommendations of the powder manufacturer.

The wear of sealing coatings after testing the sealing effect on the coatings applied on the parts of the TV2-117A turbojet engine compressor at the test station and on the Mi-8 (HT-40) helicopter intended for trial testing was less than the tolerance of the machining of sealing coatings. The wear of the $\mathrm{Ni}-25 \%$ graphite coating on the focusing devices of IV - IX degrees of the compressor motor was $0.033 \mathrm{~mm}$. The tolerance of the machining of the $\mathrm{Ni}-25 \%$ graphite sealing layer in the focusing devices is $0.05 \mathrm{~mm}$. The wear of the $\mathrm{Ni}$ $15 \%$ graphite coating on the compressor front body was $0.015 \mathrm{~mm}$. The tolerance of the machining of the $\mathrm{Ni}-15 \%$ graphite sealing layer in the front body of the compressor is $0.02 \mathrm{~mm}$. The wear of the $\mathrm{Ni}$ $25 \%$ graphite coating on the compressor working ring of $\mathrm{V}-\mathrm{X}$ degrees was $0.031 \mathrm{~mm}$. The tolerance of the machining of the $\mathrm{Ni}$ $25 \%$ graphite sealing layer in the compressor working ring is 0.05 $\mathrm{mm}$. The consumption of the AISi12 polyester coating on the compressor air ring was $0.025 \mathrm{~mm}$. The tolerance of the machining for the AISi12 - polyester layer is $0.05 \mathrm{~mm}$. The wear in coatings on all parts was within the permissible machining tolerance for the top sealing layer. Low consumption of sealing coatings has enabled keeping the clearance at the lowest value which reflected to the degree of efficiency of the compressor and fuel consumption. Small wear of APS - sealing coatings increased a degree of efficiency of the compressor by $10 \%$ while reducing fuel consumption by $8 \%$. 


\section{Conclusion}

The research into the application of APS soft abrasive coatings on parts of the TV2 - 117A turbojet engine compressor has shown that there was a significant influence of the type of technology and materials on the effect of sealing the compressor and on keeping the clearance in exploitation at the minimum value. The sealing coating systems have shown that their characteristics significantly affect the performance of the compressor during engine operation. The analysis of the structural and mechanical characteristics of the coatings in the laboratoryas well as the 42-hour testing of the compressor parts at the test station and on the Mi8 (HT-40) test helicopter has shown the following:

The layers of bond and sealing coatings in the deposited state had good structural - mechanical properties that satisfy the criteria prescribed by Pratt \& Whitney and Turbomeca standards. There are no macrocracks and micro-crack networks on the surfaces of the sealing coatings. The surface of the coatings had no traces of cracks and grooves of scraping blades. Segment separation of the coating parts from the surface was not found on the sealing coatings.

The sealing coating systems had good adhesion and cohesive strength of layers in exploitation. The compressor parts did notshow the delamination of coatings, the peeling of coatings through layers or the separation of coating layers from the surface of the parts.

There is no ovality on the inner surfaces of the compressor parts, which shows even wear of sealing coatings in exploitation. The average value of wear on the sealing coating of $\mathrm{Ni}-25 \%$ graphite on the directional devices of IV-IX degrees was $0.033 \mathrm{~mm}$. On the sections of the compressor front body, the average value of wear on the sealing coating of $\mathrm{Ni}-15 \%$ graphite was $0.015 \mathrm{~mm}$. On the compressor working ring of $\mathrm{V}-\mathrm{X}$ degrees, the average value of the wear of the Ni-25\% graphite coating was $0.031 \mathrm{~mm}$. The AISi - polyester sealing coating on the compressor air labyrinth ring had wear of $0.025 \mathrm{~mm}$. On all parts of the TV2 -117 A engine compressor, the wear of the sealing coatings was less than the permitted machining tolerances. Low consumption of sealing layers provided the minimum clearance and efficient sealing while reducing the loss of pressure in the compressor. This has increased the level of efficiency of the compressor by $10 \%$ while reducing fuel consumption by $8 \%$. The results of the research show that binary sealing coatings have been successfully applied in the process of general repair of the TV2 117A turbojet engine compressor. 


\section{Literature}

Brossard, S., Munroe, P.R., Tran, A.T.T., \& Hyland, M.M. 2009. Study of the effects of surface chemistry on splat formation for plasma sprayed $\mathrm{NiCr}$ onto stainless steel substrates. Surface\&Coatings Technology, pp.1-9. SCT-15342.

Demasi, J.T. 1994. Protective coating in the gas turbine engine. Surf. Coat. Technol, 68-69, pp.1-9.

Knotek, O., Lugscheider, E., \& Cremer, K.H. 1980. Alumina and Alurninide Formation in Nickel Aluminum Spraying Powders. . In: Proceedings of Ninth International Thermal Spray Conference. The Hague, pp.282-286

Metco 443NS Nickel-Chromium/Aluminum Composite Powder 2000. Sulzer Metco. Technical Bulletin 10-130.

Metco 450NS Nickel / Aluminum Composite Powder 2000. Sulzer Metco. Technical Bulletin 10-136.

Metco 307NS - 1, Metco 308NS - 1 Nickel Graphite Powder 2000. Sulzer Metco. Technical Bulletin 10-115. 10-141.

Metco 601NS Aluminum - Polyester Powder 2000. Sulzer Metco. Technical Bulletin

Mrdak, M. 2010. Uticaj brzine depozicije praha na mehaničke karakteristike i strukturu APS - NiCr/Al prevlake. Vojnotehnički glasnik / MilitaryTechnical Courier, 58(4), pp.5-16.

Mrdak, M. 2012a. Study of the properties of plasma deposited layers of nickelchrome-aluminum-yttrium coatings resistant to oxidation and hot corrosion. Vojnotehnički glasnik / MilitaryTechnical Courier, 60(2), pp.182-201.

Mrdak, M. 2012b. Study of the characteristics of plasma spray sealing aluminum silicon- polyester coatings. Vojnotehnički glasnik / MilitaryTechnical Courier, 60(3), pp.71-89.

Mrdak, M. 2013a. Characterization of nickel - graphite sealing coatings in the system with the nickel - aluminum bonding coating. Vojnotehnički glasnik / MilitaryTechnical Courier, 61(1), pp.69-88.

Mrdak, M., Vencl, A., Nedeljkovic, B., \& Stanković, M. 2013. Influence of plasma spraying parameters on properties of the thermal barrier coatings. Materials Science and Technology, 29(5), pp.559-567.

Mrdak, M. 2013b. Structure and properties of plasma sprayed APS - Ni20Al coatings. Vojnotehnički glasnik / Military Technical Courier, 61(2), pp.7-22.

Mrdak, M. 2014a. Characterization of the wear resistant aluminum oxide $40 \%$ titanium dioxide coating. Vojnotehnički glasnik / MilitaryTechnical Courier, 62(1), pp.7-22.

Mrdak, M. 2014b. Mechanical Properties and Microstructure of Vacuum plasma Sprayed Cr3C2-25(Ni20Cr) Coatings. Vojnotehnički glasnik glasnik / MilitaryTechnical Courier, 62(2), pp.7-26.

Naser, H. 1988. Some Areas of Application of Plasma Spry Coatings in the Field of Aviation. . In: 1st Plasma Technik Symposium, Lucerne, pp.75-84

Novinski, E.R. 1990. Process parameter impact on the physical properties of an advanced abradable coating. In: Proceedings of 3rd National Thermal Spray Conference. USA, pp.151-157

Novinski, E.R. 1991. The design of thermal sprayed abradable seal coatings for gas turbine engines. In: Proceedings of 4th National Thermal Spray Conference. USA, pp.451-454

Oka, T. 1990. Basic characteristic of different abradable coatings. In: Proceedings of International Thermal Spraying Conference. Germany, pp.58-67 
Svantesson, J., \& Wigren, J. 1992. A Study of Ni-5wt.\% Al coatings produced from different feedstock powder. Journal of Thermal Spray Technology, 1(1), pp.65-70. doi:10.1007/BF02657019

Tosnar, L. 1988. Plasma Sprayed Seal Coatings. . In: Proc. Plasma Technik Symposium, Lucerne. , pp.257-262

Turbojet Engine - Standard Practices Manual (PN 582005) 2002. East Hartford, USA: Pratt \& Whitney.

Turbojet engine-standard practices manuel, TURBOMECA .

Vencl, A., Arostegui, S., Favaro, G., Zivic, F., Mrdak, M., Mitrović, S., \& Popovic, V. 2011. Evaluation of adhesion/cohesion bond strength of the thick plasma spray coatings by scratch testing on coatings cross-sections. Tribology International, 44(11), pp.1281-1288.

Yi, M. 1997. Erosion wear of AISi-graphite and Ni/graphite abradable seal coating. Trans. Nonferrons Met. Soc. China (English letter), 8(2), pp.99-102.

Yi, M. 1999. Friction and wear behaviour and abradability of abradable seal coating. Wear, 231, pp.47-53.

\section{АНАЛИЗ ЭФФЕКТА УПЛОТНЕНИЯ КОМПРЕССОРА ТУРБОРЕАКТИВНОГО ДВИГАТЕЛЯ ТV2-117А ПОД ВОЗДЕЙТВИЕМ ПЛАЗМЕННОГО НАПЫЛЕНИЯ ИЗНОСОСТОЙКИХ ПОКРЫТИЙ}

ОБЛАСТЬ: химические технологии

ВИД СТАТЬИ: оригинальная научная статья

ЯЗЫК СТАТЬИ: английский

Резюме:

Данное исследование раскрывает эфффект уплотнения, нанесенного атмосферным плазменным напылением, на отдельные детали коспрессора турбореактивного двигателя TV2-117A. Впервые такой метод покрытия был применен по западной технологии плазменного напыления. С целью замены существующих уплотнительных материалов новыми классами материалов, обеспечивающих лучший эффрект уплотнения и проход воздуха под высоким давлением через компрессор. Мягкие уплотнители разработаны в виде двойной системы, состоящей из нижнего слоя на базе NiCrAl и NiAl покрытия и верхнего слоя уплотнения на базе $\mathrm{Ni}$ - 15\% графрuma, $\mathrm{Ni}$ - 25\% графрита и AISi - полиэстера.

В данной работе приведены параметры нанесения покрытия на детали компрессора, механические и микроструктурные харатеристики покрытия и соответствующий способ его нанесения. При анализе механических свойств покрытия применялся метод измерения микротвёрдости соединительных слоев HV0.3 и макротвердости уплотняющего слоя методом HR15W.

Были проведены испытания на растяжение до разрыва растягивающего напряжения слоев двойного покрытия. Микроструктура слоя была исследована под оптическим микроскопом - ОМ. 
Оценка микроструктуры нанесенных слоев покрытия выполнена в соответствии со стандартными требованиями, предписанными производителями Pratt-Whitney и TURBOMECA.

Износ покрытия был определен сравнительным методом дефрормации уплотнительного слоя до и после проведения испытаний. Контроль формы был выполнен на координатно-измерительной машине MAUSER ML 28. В статье приводятся: средний процент износа, выраженный в мм и удельный процент износа механически обработанных деталей компрессора.

Испытания эффректа уплотнения деталей компрессора двигателя TV2-117А были проведены на летно-испытательной станции, при использовании вертолета Мi-8(HT-40). Проведенные испытания показали, что при применении новой системы уплотнительных покрытий увеличивается эфффективность компрессора на 10\%, при одновременном снижении расхода топлива на $8 \%$.

Ключевые слова: уплотнители, слои, двигатели, нанесение, компрессоры, покрытие.

ISTRAŽIVANJE UTICAJA PLAZMA SPREJ ZAPTIVNIH PREVLAKA NA EFEKAT ZAPTIVANJA KOMPRESORA TURBOMLAZNOG MOTORA TV2 - 117A

OBLAST: hemijske tehnologije

VRSTA ČLANKA: originalni naučni članak

JEZIK ČLANKA: engleski

Sažetak:

U ovom istraživanju prikazan je efekat primene mekih zaptivki deponovanih atmosferski plazma sprej - APS procesom na delovima kompresora turbomlaznog motora TV2-117A. Na delovima kompresora primenjena je prvi put zapadna plazma sprej tehnologija i materijali. Cilj je bio da se izvrši supstitucija postojećeg zaptivnog materijala sa novom klasom materijala, da bi se povećao efekat zaptivanja i obezbedio protok vazduha pod najvećim pritiskom kroz kompresor. Meke zaptivke su formirane kao dupleks sistemi koji se sastoje od donjeg veznog sloja na bazi NiCrAl i NiAl prevlaka i gornjih zaptivnih prevlaka na bazi slojeva $\mathrm{Ni}-15 \%$ grafita, $\mathrm{Ni}-25 \%$ grafita i AISi - poliestera. U radu su prikazani parametri sa kojima su deponovane prevlake na delovima kompresora, mehaničke i mikrostrukturne karakteristike prevlaka proizvedenih sa optimalnim parametrima depozicije. Procena mehaničkih karakteristika prevlaka urađena je ispitivanjem mikrotvrdoće veznih slojeva metodom $\mathrm{HV}_{0.3}$ i makrotvrdoće zaptivnih slojeva metodom HR15W. Zatezne čvrstoće spoja dupleks sistema prevlaka ispitane su metodom kidanja na zatezanje. Mikrostrukture slojeva prevlaka su procenjene na optičkom mikroskopu - OM. Analiza mikrostruktura depono- 
vanih slojeva urađena je u skladu sa standardom Pratt-Whitney $i$ TURBOMECA. Pohabanost prevlaka određena je na osnovu promene dimenzija zaptivnih površina pre i posle ispitivanja. Merenje dimenzija rađeno je na koordinatnoj mernoj mašini MAUSER ML 28. U radu je prikazana srednja vrednost pohabanosti izražena u $\mathrm{mm}$ i upoređena sa vrednostima dozvoljenih tolerancija mašinski obrađenih delova kompresora. Efekat zaptivanja delova kompresora ispitan je u sklopu motora TV2-117A na ispitnoj stanici i letnim ispitivanjem na helikopteru Mi8(HT-40). Ispitivanja su pokazala da je novim sistemom zaptivnih prevlaka povećan stepen iskorišćenja kompresora za 10\% uz smanjenu potrošnju goriva za $8 \%$.

Uvod

Razvoj novih generacija turbomlaznih motora i zahtev za veću pouzdanost rada i resurs delova u eksploataciji, uticao je na veću primenu plazma sprej prevlaka. Razvijene su različite vrste kvaliteta prahova koji se primenjuju na komponentama vazduhoplova kao što su: komponente niskog i visokog pritiska kompresora, komponente gasne turbine $i$ komponente stajnog trapa (Mrdak, M., 2012b, pp.71-89), (Mrdak, M., 2013a, pp.69-88), (Vencl, A., et al., 2011, pp.1281-1288), (Mrdak, et al., 2013, pp.559-567), (Mrdak, M., 2014a, pp.7-22), (Mrdak, M., 2014b, pp.7-26). Na komponentama kompresora niskog i visokog pritiska turbomlaznog motora primenjuju se meke abrazivne prevlake koje uzrokuju niskoenergetske uslove trenja, koje su otporne na eroziju. Sistemi zaptivnih prevlaka konstruisani su tako da se uzima u obzir nesaosnost rotora i dimenzionalne promene uzrokovane promenom temperature. Zaptivni sistemi prevlaka konstruisani su tako da se habaju bez oštećenja vrhova lopatica održavajući konstantan zazor (Tosnar, L., 1988, pp.257-262). Kod zaptivnih sistema koji se troše - consumption, potrebno je uravnoteženje između trošenja materijala pod uticajem toplote, završne površinske obrade, otpornosti na eroziju i otpornosti na habanje. Sa plazma sprej parametrima depozicije prahova omogućena je kontrola navedenih kritičnih karakteristika. Plazma sprej proces depozicije omogućuje kontrolu poroznosti, gustine i debljine prevlaka da bi se dobili zaptivni slojevi traženih karakteristika (Tosnar, L., 1988, pp.257-262). Meke zaptivne prevlake formiraju se kao dupleks sistemi sa plazma sprej tehnologijom. Za izradu donjeg veznog sloja često se koriste prahovi NiAl, NiCrAl i NiCrAlY (Mrdak, M., 2010, pp.5-16), (Mrdak, M., 2013b, pp.7-22), (Mrdak, M., 2012a, pp.182-201). Debljina veznog sloja se kreće od 0,005 $0,15 \mathrm{~mm}$ i mora da bude usklađena sa materijalom substrata i gornjim zaptivnim slojem. Uloga veznog sloja je da omogući dobru adheziju sa substratom i dobru vezu sa gornjim zaptivnim slojem. Spoljni sloj ima osnovnu funkciju zaptivanja. Svetska istraživanja u ovoj oblasti su podstakla na primenu novih materijala i plazma sprej tehnologije u postupku remonta kompresora turbomlaznog motora TV2-117A koji se proizvodi u Rusiji. Da bi se ostvarili postavljeni ciljevi, zazori između komponenti u 
kompresoru moraju da budu minimalni (Demasi, J.T., 1994, pp.1-9). Veoma dobro zaptivanje gasa koji protiče kroz kompresor smanjuje gubitke gasa uzrokovane curenjem. Takođe, zaptivke treba da obezbede toplotnu izolaciju kućišta, i smanje uticaj temperature gasa u kućištu (Novinski, E.R., 1991, pp.451- 454), (Yi, M., 1999, pp.47-53). Za tu namenu koriste se prevlake koje se sastoje od metalne faze i nemetalne faze za samo - podmazivanje sa visokom poroznošću (Oka,T., 1990, pp.58-67). Najvažnija svojstva koja treba da poseduju zaptivne prevlake su velika otpornost na trošenje struganjem lopatica $i$ otpornost na eroziju gasa $i$ stranih čestica koje su prisutne u gasu (Novinski, E.R., 1990, pp.151157), (Yi,M., 1997, pp.99-102).

Cilj istraživanja bio je da se plazma sprej tehnologijom i novim materijalima ispita efekat zaptivanja kompresora turbomlaznog motora TV2 - 117A i izvrši supstitucija postojećih zaptivnih materijala u remontu motora. Nove generacije materijala koje se primenjuju kao zaptivke na delovima kompresora motora trebale bi da boljom zaptivnošću obezbede veći stepen iskorišćenja kompresora uz smanjenu potrošnju goriva. Uslov koji treba da ispune primenjeni materijali na delovima kompresora su da zaptivanjem obezbede protok vazduha temperature $t=100-125^{\circ} \mathrm{C} \mathrm{kroz} \mathrm{kompresor} \mathrm{pod} \mathrm{najvećim} \mathrm{pritiskom.} \mathrm{Očekivani}$ efekti su potvrđeni 42 časovnim ispitivanjem motora na ispitnoj stanici i letnim ispitivanjem na helikopteru Mi-8 (HT-40).

Materijali i eksperimentalni detalji

Za istraživanje zaptivnih prevlaka upotrebljeno je pet različitih prahova firme Sulzer Metco sa oznakom: Metco 443NS, Metco 450NS, Metco 307NS-1, Metco 308NS-1 i Metco 601 NS. Čestice kompozitnih prahova Metco 443NS (NiCr/Al) i Metco 450NS (Ni/Al) izrađene su tehnikom suvog raspršivanja. Prah NiCr/Al sastoji se od $94 \% \mathrm{NiCr}(75 \% \mathrm{Ni}$, $19 \% \mathrm{Cr}$ ) i $6 \% \mathrm{Al}$. Temperatura topljenja NiCr legure je $1339^{\circ} \mathrm{C}$, a aluminijuma $660^{\circ} \mathrm{C}$. Prah je imao raspon granulacije od $-120+45 \mu \mathrm{m}$. Čestice kompozitnog praha $\mathrm{Ni} / \mathrm{Al}$ se sastoje od $95,5 \% \mathrm{Ni} \mathrm{i} 4,5 \% \mathrm{Al}$. Prah je imao raspon granulacije $88+45 \mu \mathrm{m}$. Za izradu mekih zaptivnih prevlaka namenjenih za rad do $480^{\circ} \mathrm{C}$ koristili su se kompozitni prahovi Metco 307NS-1(Ni/25\%grafit) $i$ Metco 308NS-1(Ni/15\%grafit). Prahovi su proizvedeni oblaganjem čestica grafita sa česticama Ni postupkom suvog raspršivanja. Temperatura topljenja prahova Ni-25\%grafit i Ni-15\%grafit je $1455^{\circ} \mathrm{C}$. Prahovi su imali raspon granulata od $-90+30 \mu \mathrm{m}$. Za izradu meke zaptivke namenjene za rad do $345^{\circ} \mathrm{C}$ koristila se mehanička mešavina prahova AlSi12 i poliestera. Prah se sastoji od 60\% legure AlSi12 i 40\% poliestera. Temperatura topljenja AISi12 praha je $425^{\circ} \mathrm{C}$ koji je imao raspon granulacije čestica od $-106+10 \mu m$. Materijal substrata uzoraka na kome su deponovani slojevi sistema zaptivnih prevlaka bio je od nerđajućeg čelika X15Cr13 (EN 1.4024) u termički neobrađenom stanju. Ispitivanje mehaničkih karakteristika slojeva prevlake rađeno je prema standardu Pratt \& Whitney. Za ispitivanje tvrdoće i za procenu mikrostrukture u deponovanom stanju zaptiv- 
nih sistema prevlaka napravljeni su uzorci od čelika Č.4171 (X15Cr13 EN10027) dimenzija $70 \times 20 \times 1,5 \mathrm{~mm}$. Ispitivanje mikrotvrdoće veznih prevlaka NiAl i NiCrAl rađeno je metodom $\mathrm{HV}_{0.3}$, a makrotvrdoće zaptivnih prevlaka Ni-15\%grafit, Ni-25\%grafit i AlSi12-poliester rađeno je metodom HR15y korišćenjem Rockwell čelične kugle prečnika 12,7 mm i opterećenje od $15 \mathrm{~kg}$. Uzorci za ispitivanje čvrstoće spoja napravljeni su od istog čelika dimenzija $\varnothing 25 \times 50 \mathrm{~mm}$. Testovi zatezne čvrstoće spoja su vršeni na sobnoj temperaturi na hidrauličnoj opremi sa brzinom od $10 \mathrm{~mm} / \mathrm{min}$. Mikrostruktura deponovanih slojeva ispitana je na optičkom mikroskopu OM. Kompresor na kome su primenjene prevlake se sastojao od usmeravajućeg aparata od IV - IX stepena, prednjeg tela kompresora, radnih prstenova kompresora od $V$ - $X$ stepena $i$ prstena vazdušnog labirinta napravljenih od legure titana namenjene za vazduhoplovnu vojnu industriju. Legura titana je ruske oznake OST 1 90173-75 (VT-5) sa sadržajem aluminijuma od 4.3-6.2\% Al. U ovom eksperimentu korišćen je atmosferski plazma sistem firme Plazmadayn i plazma pištolj MINI - GUN II. Urađen je veliki broj uzoraka, a u radu su prikazani optimalni parametri sa kojima su deponovane prevlake na delovima kompresora, koji su ispitani u sklopu turbomlaznog motora TV2-117A na ispitnoj stanici i na helikopteru Mi-8 (HT-40) namenjenom za probna letna ispitivanja. Prevlake su deponovane na ohrapavljene i predgrejane uzorke i delove kompresora na temperaturi od $90-120^{\circ} \mathrm{C}$. Zbog geometrije delova: usmeravajućeg aparata od IV - IX stepena, prednjeg tela kompresora, radnih prstenovima kompresora od $V$ - X stepena i prstena vazdušnog labirinta, deponovanje prahova je rađeno sa specijalno konstruisanim plazma pištoljem MINI - GUN II dimenzija Ø25 X $600 \mathrm{~mm}$. Plazma pištolj se sastojao od : anode A 2084 F65, katode K 1083A - 129 i gas injektora GI 2084 B - 103. Depozicija svih prevlaka urađena je sa snagom napajanja od 40KW. Vezni slojevi NiCrAl i NiAl prevlaka deponovani su sa mešavinom plazma gasovima Ar$\mathrm{He}$, a slojevi zaptivnih prevlaka sa Ar bez sekundarnog plazma gasa He.

Urađena su tri tipa sistema zaptivnih prevlaka kao što su: NiCrAl / Ni - 15\% grafit, NiCrAl / Ni - 25\% grafit i NiAl / AlSi12 - poliester. Na svim delovima, debljina veznih NiCrAl slojeva po jednom prolazu plazma pištolja bila je $25 \mu \mathrm{m}$. Debljine zaptivnih Ni - 15\%grafit i Ni - 25\% grafit slojeva po jednom prolazu plazma pištolja bila je 60 $\mu$ m. Debljina deponovanog NiAl sloja na prstenu vazdušnog labirinta sa jednim prolazom plazma pištolja bila je $20 \mu m$. Debljina zaptivnog AlSi12 - poliester sloja na prstenu vazdušnog labirinta sa jednim prolazom plazma pištolja bila je $100 \mu \mathrm{m}$.

Debljina veznih slojeva deponovanih sa prahom NiCrAl bila je od 0,1 - 0,15 mm, a debljina zaptivnih prevlaka izrađenih od praha Ni$25 \%$ grafit bila je od 0,65 - 0,7 mm. Debljine zaptivnih prevlaka uvećane su za 0,3 mm zbog mašinske obrade prevlaka.

Na prednjem telu kompresora, debljina veznih slojeva deponovanih sa prahom NiAl bila je od 0,1 - 0,15 mm, a debljina gornjih zaptivnih prevlaka izrađenih od praha Ni-15\%grafit bila je od 0,65-0,7 mm. Debljine zaptivnih prevlaka uvećane su za 0,3 mm zbog mašinske obradu prevlaka. 
Na radnim prstenovima kompresora od $\mathrm{V}$ - $X$ stepena, deponovani su slojevi vezne prevlake NiCrAl debljine od 0,15-0,2 mm. Debljine gornjih zaptivnih prevlaka deponovanih sa prahom $\mathrm{Ni}-25 \%$ grafit bile su debljine od 0,8 - 0,85 mm. Takođe, zbog dodataka za mašinsku obradu prevlaka debljine zaptivnih prevlaka su uvećane za 0,3 $\mathrm{mm}$.

Na prstenu vazdušnog labirinta, vezni sloj prevlake je izrađen od praha NiAl sa debljinom od 0,1 - 0,15 mm, a gornji zaptivni sloj prevlake od praha AlSi12-poliester sa debljinom od 0,6 - 0,65 $\mathrm{mm}$. U debljinu zaptivnog sloja uračunat je dodatak od 0,3 $\mathrm{mm}$ za mašinsku obradu prevlake.

Mašinska obrada zaptivnih prevlaka Ni-15\%grafit, Ni-25\%grafit i AlSi12 - poliester prevlake deponovanih na delovima kompresora urađena je metodom struganja gruba obrada i struganjem fina obrada sa reznim alatom - nožem sa WC pločicom.

\section{Rezultati i diskusija}

Slojevi vezne prevlake NiCrAl ravnomerno su deponovani na usmeravajućem aparatu sa dobrim mehaničkim i strukturnim karakteristikama. Vezna prevlaka NiCrAl imala je vrednosti mikrotvrdoće od 308 - $325 \mathrm{HV}_{0.3}$. Vrednosti su iznad min.170HV 0.3 koje propisuje standard TURBOMECA. Zatezna čvrstoća spoja sistema NiCrAl / Ni - 25\% grafit prevlaka je imala vrednost $43 \mathrm{MPa} i$ iznad je minimalne vrednosti $32 \mathrm{MPa}$ propisane standardom TURBOMECA. Prevlaka se sastoji od lamela čvrstog rastvora hroma i aluminijuma u niklu $\mathrm{Y}-\mathrm{Ni}(\mathrm{Cr}, \mathrm{Al})$ svetlo plave boje i međulamelarni oksidnih faza $\mathrm{NiO}, \mathrm{NiCr}_{2} \mathrm{O}_{3}, \mathrm{Cr}_{2} \mathrm{O}_{3}, \mathrm{CrO}_{3}$ ravnomerno raspoređenih po granicama lamela čvrstog rastvora tamnije plave boje označene crvenim strelicama (Brossard, et al., 2009, pp.1-9), (Mrdak, 2012, pp.5-16), (Mrdak, 2012a, pp.182-201). Zaptivna prevlaka $\mathrm{Ni}$ - 25\%grafit imala je vrednosti makrotvrdoće u rasponu od 78 - 83 HR15y. Tvrdoće su bile dosta ujednačene, što ukazuje da su slojevi $\mathrm{Ni}$ - 25\%grafit prevlake kontinualno i ravnomerno deponovani na veznim slojevima. Analiza mikrofotografija je pokazala da je u slojevima vezne prevlake NiCrAl udeo mikro pora bio do $2 \%$. Analiza mikrofotografija je pokazala da je u slojevima zaptivne $\mathrm{Ni}$ - 25\% grafit prevlake udeo mikro pora bio $16 \%$, što je u skladu sa standardom i propisom proizvođač praha. Na telu kompresora deponovani su sistemi zaptivnih prevlaka NiAl/Ni-15\%grafit. Vezna prevlaka NiAl imala je vrednosti mikrotvrdoće od 165 - $181 \mathrm{HV}_{0.3}$, a slojevi zaptivne prevlake Ni-15\%grafit od 86 - 89 HR15 y. Čvrstoća spoja sistema NiAl/Ni-15\%grafit prevlaka imala je vrednost $44 \mathrm{MPa}$. Mehaničke karakteristike mikrotvrdoće i zatezne čvrstoće spoja sistema zaptivnih prevlaka NiAl / Ni-15\%grafit iznad su minimalnih vrednosti koje propisuje standard Pratt \& Whitney (min.140 HV $\mathrm{HV}_{0.3}$ i min.35 MPa). Analiza mikrofotografija vezne prevlake NiAl pokazala je da je udeo mikro pora bio ispod $2 \%$. U slojevima zaptivne Ni - 15\%grafit prevlake udeo mikro pora bio je $13 \%$, što je manji udeo u odnosu na zaptivnu prevlaku Ni - 25\%grafit. Sistem zaptivne prevlake NiAI/AISi12 poliester deponovan je na prstenu vazdušnog la- 
birinta. Vezna prevlaka NiAl deponovana je sa vrednostima mikrotvrdoće od 178 - 203HV $V_{0.3}$, a zaptivna prevlaka AlSi12 poliester sa vrednostima od 72 - 75 HR15y. Zatezna čvrstoća spoja zaptivne prevlake AlSi12 - poliester u sistemu sa veznom prevlakom NiAl iznosila je 30 MPa. Mehaničke karakteristike su bile u skladu sa standardom Pratt \& Whitney. Analiza mikrofotografija vezne prevlake NiAl pokazala je da je udeo mikro pora bio oko $2 \%$ a u zaptivnoj prevlaci AlSi12 je udeo mikro pora bio 5\%. Vezna prevlaka NiCrAl deponovana na radnim prstenovima imala je vrednosti mikrotvrdoće od $305-331+\mathrm{VV}_{0.3}$. Zaptivna prevlaka $\mathrm{Ni}$ - 25\%grafit imala je vrednosti makrotvrdoće u rasponu od 79 - 84 HR15y. Čvrstoća spoja sistema NiCrAl / Ni - 25\% grafit prevlaka je imala vrednost $43 \mathrm{MPa}$. Vrednosti mikrotvrdoće i zatezne čvrstoće spoja iznad su minimalnih vrednosti koje propisuje standard TURBOMECA (min.170HV ${ }_{0.3}$ i 35MPa). Analiza mikrofotografija je pokazala da je u slojevima prevlake NiCrAl udeo mikro pora bio ispod $2 \%$, a u slojevima Ni - 25\%grafit prevlake $17 \%$, što je u skladu sa standardom I preporukom proizvođača praha. Pohabanost Ni-25\% grafit prevlake na usmeravajućim aparatima od IV - IX stepena kompresora motora bila je 0,033 mm. Tolerancija mašinske obrade za zaptivni sloj Ni-25\% grafit na usmeravajućim aparatima je 0,05 $\mathrm{mm}$. Pohabanost Ni-15\% grafit prevlake na prednjem telu kompresora bila je 0,015mm.Tolerancija mašinske obrade za zaptivni sloj Ni-15\% grafit na prednjem telu kompresora je 0,02 $\mathrm{mm}$. Pohabanost $\mathrm{Ni}-25 \%$ grafit prevlake na radnim prstenovima kompresora od $V$ - X stepena je bila $0,031 \mathrm{~mm}$. Tolerancija mašinske obrade za zaptivni sloj Ni-25\% grafit na radnim prstenovima kompresora je 0,05 mm. Potrošnja AlSi12-poliester prevlake na prstenu vazdušnog labirinta je bila $0,025 \mathrm{~mm}$. Tolerancija mašinske obrade za AlSi12 - poliester sloj je 0,05 mm. Pohabanost prevlaka na svim delovima je bila u dozvoljenim tolerancijama mašinske obrade za gornji zaptivni sloj.

Zaključak

Istraživanja primene APS mekih abrazivnih prevlaka na delovima kompresora turbomlaznog motora TV2 - 117A pokazala su da postoji veliki uticaj vrste tehnologije i materijala na efekat zaptivanja kompresora i na održavanje minimalnog zazora u eksploataciji. Sistemi zaptivnih prevlaka su pokazali da sa svojim karakteristikama bitno utiču na performanse kompresora u toku rada motora. Analizom strukturnih $i$ mehaničkih karakteristika prevlaka u laboratorijskim uslovima $i$ ispitivanjima delova kompresora u sklopu na ispitnoj stanici od 42 časa i letnim ispitivanjem na probnom helikopteru Mi-8(HT-40) ustanovljeno je sledeće: Slojevi veznih i zaptivnih prevlaka u deponovanom stanju imali su dobre strukturno - mehaničke karakteristike koje zadovoljavaju kriterijume propisane standardima Pratt \& Whitney i TURBOMECA. Na površinama zaptivnih prevlaka nisu prisutne makro prskotine i mreže mikro prskotina. Površina prevlaka je bila bez tragova riseva i brazda 
od struganja lopatica. Na zaptivnim prevlakama nije uočeno segmentno odvajanje delova prevlake sa površine. Sistemi zaptivnih prevlaka imali su dobru adhezionu i kohezionu čvrstoću slojeva u eksploataciji. $\mathrm{Na}$ delovima kompresora nije uočeno raslojavanje prevlaka, ljuštenje prevlaka kroz slojeve i odvajanje slojeva prevlaka sa površina delova. Na unutrašnjim površinama delova kompresora nema ovalnosti što govori o ravnomernom habanju zaptivnih prevlaka u eksploataciji. Prosečna vrednost pohabanosti zaptivne prevlake Ni-25\% grafit na usmeravajućim aparatima od IV-IX stepena bila je 0,033 $\mathrm{mm}$. Na sekcijama prednjeg tela kompresora, prosečna vrednost pohabanosti zaptivne prevlake Ni-15\%grafit bila je 0,015 mm. Na radnim prstenovima kompresora od V-X stepena, prosečna vrednost pohabanosti prevlake Ni$25 \%$ grafit bila je 0,031 mm. Zaptivni sloj AISi - poliester na prstenu vazdušnog labirinta pohaban je 0,025 mm. Na svim delovima kompresora motora TV2 -117 A pohabanost zaptivnih prevlaka bila je manja od dozvoljene tolerancije za mašinsku obradu delova. Mala potrošnja zaptivnih slojeva obezbedila je minimalni zazor i efikasno zaptivanje i smanjila gubitke pritiska u kompresorima. Ovim je povećan stepen iskorišćenja kompresora za $10 \%$ uz smanjenu potrošnju goriva za $8 \%$. Na osnovu dobijenih rezultata istraživanja, dvojni sistemi zaptivnih prevlka se uspešno primenjeni u postupku opšte opravke kompresora turbomlaznog motora TV2 - 117A.

Ključne reči: zaptivke, slojevi, motori, depoziti, kompresori, prevlake.

Datum prijema članka/Paper received on: 10. 06. 2014.

Datum dostavljanja ispravki rukopisa/Manuscript corrections submitted on: 21. 06. 2014. Datum konačnog prihvatanja članka za objavljivanje/ Paper accepted for publishing on: 23. 06. 2014. 